\title{
РОЛЬ ВОКАЛЬНО-ХУДОЖНЬОГО РЕПЕРТУАРУ В СИСТЕМІ НАВЧАННЯ Й У ПРОФЕСІЙНІЙ ДІЯЛЬНОСТІ ЕСТРАДНОГО СПІВАКА
}

\begin{abstract}
Анотація. Статтю присвячено визначенню ролі вокально-художнього репертуару в системі навчання й у професійній діяльності естрадного співака. Головну увагу зосереджено на важливості вмілого складання і володіння репертуаром з метою удосконалення вокально-виконавської майстерності. Окреслено основні принципи добору і корегування репертуару. Запропоновано класифікацію вокальних творів для підготовки естрадних співаків, в якій виділено романси, арії з популярних опер, оперет, мюзиклів, естрадні пісні, народно-пісенну творчість. Обгрунтовано, що ефективний добір цікавого вокально-художнього репертуару сприяе підвищенню рівня успішності студента. Узагальнено, що фрункції репертуару виявляються як в діевості засобів покращення якості навчального процесу, так і в профресійній музичній комунікації.
\end{abstract}

Ключові слова: вокально-художній репертуар, вокальний твір, естрадний спі-вак, вокально-виконавська майстерність, творча діяльність.

Faryna Nataliia, Ushakova Oksana Rivne State Humanitarian University

\section{THE ROLE OF VOCAL AND ARTISTIC REPERTOIRE IN THE SYSTEM OF EDUCATION AND IN THE PROFESSIONAL ACTIVITY OF A POP SINGER}

Summary. The article is devoted to defining the role of vocal and artistic repertoire in the system of education and in the professional activity of a pop singer. The main focus is on the importance of skillful composition and mastery of the repertoire in order to improve vocal and performing skills. The repertoire forms the creative face of the vocalist, the style of performance, demonstrates talent, develops creative ac-tivity, interests; it is a criterion of the vocalist identity. It is important to update and expand in the context of the world musical heritage of different eras, styles, directions, schools, caring for a high artistic level, genre and musical-stylistic diversity, aesthetic content and accessibility of musical and literary text, diversity melodies, rhythms, intonations and musical-artistic images. The main principles of selection and adjustment of the repertoire have been outlined. The selection of the vocal repertoire must be realized in accordance with the vocal and technical abilities, acting abilities of the vocalist, individual features of his voice, age, temperament and level of intelligence, universal moral and aesthetic values, taking into account educational value, originality, logic of concert performances. Musical styles, manners of performance must correspond to the plot, be modern and fashionable. The repertoire can be adjusted depending on the degree of assimilation. A classification of vocal works for the preparation of pop singers have been proposed. It may include not only pop songs, but also romances, arias from popular operas, operettas, musicals, folk song. The effective selection of interesting educational and artistic repertoire helps to increase the level of student success. It forms high qualification, expands musical and artistic worldview, creates productive musical and creative activities in vocal classes, enriches musical and artistic impressions. The fact that the functions of the repertoire are manifested both in the effectiveness of means of improving the quality of the educational process and in professional musical communication have been generalized.

Keywords: vocal and artistic repertoire, vocal work, pop singer, vocal and perform-ing skills, creative activity.

$\Pi$ остановка проблеми. Невід'ємною складовою фрахової підготовки естрадного співака у вищій школі і його майбутньої професійної діяльності $є$ ефективний добір вокально-художнього репертуару. У процесі удосконалення художньої і технічної сторін вокально-виконавської майстерності надзвичайно важливого значення набувае його оновлення i розширення в контексті світової музичної спадщини різних епох, стилів, напрямків, шкіл, дбаючи одночасно про високий художній рівень, жанрову та музично-стилістичну різноманітність, естетичний зміст і доступність музичного та літературного тексту, різноманітність мелодій, ритмів, інтонацій і музично-художніх образів, ураховуючи діапазон вокаліста.

Аналіз останніх досліджень і публікацій. Проблеми вибору і роботи над репертуаром у процесі організації концертно-виконавської діяльності досліджуються у наукових працях учених-мистецтвознавців, відомих виконавців, музичних педагогів, зокрема Гавацко Е. П. [1],
Горбової Н. Г. [2], Гмиріної С. В. [3], Ісупової А. В. [4], Остапенко Л. В. [5], Фарини Н. П. [7; 8], Черкасова В. Ф. [9]. Відбір музичного репертуару є одним з основних принципів музично-освітньої галузі й одним із вирішальних чинників музичного виховання $[1$, с. $69 ; 5$, с. 14$]$.

Виділення невирішених раніше частин загальної проблеми. Зважаючи на широкий контекст формування репертуару, дослідження його ролі в системі навчання у вищій школі й у професійній діяльності естрадного співака $\varepsilon$ актуа-льним науково-теоретичним та прикладним завданням у галузі музичного мистецтва. Цікавими для дослідження залишаються питання зростання вокальної майстерності і зміцнення музичної пам'яті через вміле складання та оволодіння репертуаром, оптимізацію рівня його складності, аспекти використання при цьому сучасних музичних стилів тощо.

Мета статті - дослідження ролі вокально-художнього репертуару в системі навчання і професійної діяльності естрадного співака. 
Виклад основного матеріалу. Добір цікавого музично-виконавського репертуару е суттевим чинником успішної виховної роботи засобами співу. Музикознавці і вчені-педагоги стверджують: гармонія образного яскравого тексту та виразної мелодії несе в собі неабиякий виховний потенщіал. У цьому сенсі, саме пісня, як носій різноманітних образів, є унікальним навчально-виховним матеріалом. Доторкнутись до душі, викликати співпереживання, допомогти усвідомленню таких понять, як краса, радість, добро, гідність - основна мета роботи над кожним художнім образом [4, с. 247].

Сенс творчої діяльності соліста-вокаліста полягає в тому, щоб його репертуар здійснював не лише гедонічну функцію мистецтва, а й виховну - розвивав культуру та збагачував духовність слухачів/глядачів, прищеплював гарний смак завдяки художньо досконалим творам. Складаючи репертуар, слід прагнути, аби між поетичною i музичною складовими пісні була органічна едність без естетичного різнобою, а художня цінність - такою, щоб твір і через багато-багато років після прем'єри можна було слухати із зацікавленням та естетичним задоволенням [5, с. 204-205].

Головні критерії підбору репертуару: психофізіологічні можливості вокаліста; відповідність художньої основи твору можливостям сприйняття; теситурні умови; дихання; технічні можливості твору; інтерес, який викликае твір; репетиційний план (кількість занять на тиждень); достатня кількість тво-рів [6, с. 34]. 3 перших кроків навчання співака в роботі над вокальнопедагогічним художнім репертуаром слід прищепити дбайливе уважне став-лення до поетичного тексту і глибоке проникнення в художній задум композитора [2, с. 18]. Вміле складання і володіння репертуаром дозволяе зростати у вокальній майстерності, розвивати музичну пам'ять.

Формування репертуару відбувається на конкретних художніх творах. Навчальний репертуap добирається згідно з навчальною програмою відповідно до вокально-технічних можливостей та акторських здібностей студента, індивідуальних особливостей його голосу, темпераменту і рівня інтелекту, загальнолюдських морально-естетичних цінностей $з$ метою закріплення та вдосконалення навчально-виконавських навичок, оволодіння нормами сценічної культури, накопичення різножанрового пісенного репертуару, досягнення розуміння унікальності вокаліста публікою.

Репертуар відіграе важливу роль у творчому зростанні вокаліста, формуе його творче обличчя, демонструе різні грані таланту, е критеріем самобутності виконавства, розвивае творчу активність й інтереси, формуе стиль естрадного виконавства. Створюючи репертуар, окрім художньої цінності, доступності, різноманітності, мелодійності, відповідності віку виконавців, ритмічності слід керуватися ще й такими принципами як виховне значення, оригінальність, ритмічність, логіка побудови концертних виступів.

Навчальну програму студентів класу естрадного вокалу можуть складати не лише естрадні пісні, а також арії з опер і романси (класичні та побутові) за умови відповідного аранжування музичного матеріалу (вокальної партії й ін-струментального супроводу) [3]. Музичні стилі, манери виконання повинні відповідати сюжету, бути сучасними.
Репертуар може корегуватися залежно від ступеня засвоєння. Твори, призначені для первинного вивчення, повинні відповідати оптимальним можливостям вокалістів і бути зрозумілими.

Заскладний твір може стати проблемою, що відобразиться на продуктивності роботи і викличе негативне ставлення вокаліста до твору, емоційну та фізичну втому. В той же час велика кількість легких творів у репертуарі теж повинна бути обмеженою, бо полегшений репертуар не завжди є стимулом до професійного зростання.

Ураховуючи викладене, класифікацію вокальних творів для підготовки естрадних співаків можна представити таким чином:

I. Романси:

- українських композиторів-класиків;

- сучасних українських композиторів;

- романси зарубіжних композиторів-класиків та їх послідовників.

II. Арії з популярних опер, оперет, мюзиклів.

III. Естрадні пісні:

- відомих українських композиторів;

- відомих зарубіжних композиторів;

- вокальні твори з репертуару вітчизняних

і зарубіжних виконавців мовами оригіналу;

- пісні з відомих вітчизняних та зарубіжних

кінофільмів різних років мовами оригіналу;

- ретро-пісні;

- пісні в джазовому стилі;

- пісні у роковому стилі;

- дитячі пісні.

IV. Народно-пісенна творчість:

- українські народні пісні і думи;

- пісні народів світу;

- пісні патріотичного спрямування;

- бардівські пісні.

Одним із головних завдань в системі навчання у вишій школі $є$ підвищення рівня успішності студента, який стане професійним вокалістом. 3 нашої точки зору, цьому якнайкраще сприяе саме ефективний добір вокально-художнього репертуару, що безпосередньо формуе високу кваліфікацію у галузі музичного мистецтва, розширюе музичнохудожній світогляд, від викладача вимагае знання психології студентів і створюе продуктивну музично-творчу діяльність на заняттях з вокалу, збагачуе музично-художні враження від занять.

Висновки і пропозиції. Таким чином, фрункції репертуару виявляються як в дієвості засобів покращення якості навчального процесу, оскільки він відіграе провідну роль у професійній підготовці естрадних виконавців, так і в системі професійної музичної комунікації. Репертуар вокаліста відповідно до естетич-них потреб дае можливість максимально ефективно використати основні засоби музичної виразності для вдалої виконавської інтерпретації твору, а також допомагає у формуванні цілісної системи музично-художніх знань з метою самостійного створення якісного музичного продукту.

Робота над репертуаром $е$ індивідуальною і враховуе вікові, психологічні та інші особливості естрадного співака, забезпечуючи цілісне музичне виховання, а також гармонізуе систему ціннісних музичних орієнтацій вокаліста, допомагає глибшому усвідомленню ним ролі співу в особистому і профресійному житті. Поряд із практичним значенням репертуару доречно не забувати про формування художніх смаків, стилю, світогляду співака тощо. 


\section{Список літератури:}

1. Гавацко Е. П. Формування вокальних навичок у вихованців студії естрадного співу : Науково-методичний посібник. Закарпатський інститут післядипломної педагогічної освіти. Ужкород, 2017. С. 18.

2. Горбова Н. Г. Три компоненти роботи в класі сольного співу. Мистецька освіта майбутнього: методичні аспекти : зб. матеріалів Всеукр. наук.-практ. інтернет-конф., 29 квіт. 2020 р. / за заг. ред. М. М. Бриль. Київ : ДНМЦЗКМО, 2020. С. 69.

3. Гмиріна С. В. Методи роботи студентів над вокальними творами у класі сольного співу. Музичне мистецтво в освітологічнолу дискурсі. 2019. № 4. С. 77-83.

4. Ісупова А. В. Проблема репертуару в класах сольного співу. Сучасні педагоги-композитори. Сучасна мистецька освіта: реалії та перспективи. Збірник тез науково-практичного семінару / Редкол.: О. М. Грисюк, В. М. Малиневська, С. В. Малишко, С. В. Сакір, В. М. Суховерський. Чернігів : Чернігівська філія НАКККіМ, 2018. C. 247-252.

5. Остапенко Л. Засади формування пісенного репертуару : Матеріали щорічної науково-практичної інтернетконференції професорсько-викладацького складу, докторантів, аспірантів, магістрів та студентів «Музика в діалозі з сучасністю: мистецькі, педагогічні, комунікаційні аспекти музичної культури України XXI століття». Київ : КНУКіМ, 2020. С. 204-206.

6. Рекомендації для самостійної роботи студентів мистецьких спеціальностей : Навчально-методичний посібник / Укладачі: Цюряк І. О., Федорченко В. К., Борисенко Н. С. Житомир : Вид-во ЖДУ ім. Івана Франка, 2018. C. 34.

7. Фарина Н. П. Концертно-виконавська діяльність студентів-вокалістів: педагогічний аспект. Мистецька освіта та розвиток творчої особистості : зб. наук. пр. / Ін-т мистецтвознавства, фольклористики та етнології iм. М. Т. Рильського НАН України, Uniwersytet Rzeszowski wydzial Muzyki, Рівнен. держ. гуманіт. ун-т, Ін-т мистецтв. Рівне : Волинь. Обереги, 2018. Вип. 4. С. 124-130.

8. Фарина Н. П., Тимошенко Т. Г. Студія естрадного співу в сучасній системі мистецької освіти. Нова педагогічна дулка : Науково-методичний журнал. 2020. № 1(77). С.143-147.

9. Черкасов В.Ф. Основи наукових досліджень у музичноосвітній галузі : [підручник] / Володимир Черкасов. Кіровоград : РВВ КДПУ ім. В. Винниченка; Харків : ФОП Озеров, 2017. 316 с.

\section{References:}

1. Havatsko E. P. (2018) Formuvannya vokalnykh navychok u vykhovanciv studiyi estradnogo spivu: naukovometodychnyj posibnyk [Formation of vocal skills in pupils of pop singing studio: scientific and methodical manual]. Uzhhorod: Transcarpathian Institute of Postgraduate Pedagogical Education. (in Ukrainian)

2. Gorbova N. H. (2020) Try komponenty roboty v klasi solnogo spivu [Three components of work in a solo singing class]: Proceedings of the Mysteczka osvita majbutnogo: metodychni aspekty: Vseukrayinska naukovo-praktychna internet-konferenciya (Ukraine, Kyiv, April 29, 2020) (eds. Bryl M. M.), Kyiv: Mysteczka osvita majbutnogo: metodychni aspekty, p. 69.

3. Hmyrina S. V. (2019) Metody roboty studentiv nad vokalnymy tvoramy u klasi solnogo spivu [Features of functioning and problematic issues of development of the payment system of Ukraine]. Scientific View: Musical Art in Educational Discourse, no. 4, pp. 77-83.

4. Isupova A. V. (2018) Problema repertuaru v klasax solnogo spivu. Suchasni pedagogy-kompozytory [The problem of repertoire in solo singing classes. Modern teachers-composers]: Proceedings of the Suchasna mysteczka osvita: realiyi ta perspektyvy: naukovo-praktychnyj seminar (Ukraine, Chernihiv, 2018) (eds. Hrysiuk O. M., Malynevska V. M., Malyshko S. V., Sakir S. V., Sukhoverskyi V. M.), Kyiv: Suchasna mysteczka osvita: realiyi ta perspektyvy, pp. $247-252$.

5. Ostapenko L. (2020) Zasady formuvannya pisennogo repertuaru [Principles of song repertoire formation]. Proceedings of the Muzyka $\mathrm{v}$ dialozi $\mathrm{z}$ suchasnistyu: mysteczki, pedagogichni, komunikacijni aspekty muzychnoyi kultury Ukrayiny XXI stolittya: shhorichna naukovo-praktychna internet-konferenciya profesorskovykladaczkogo skladu, doktorantiv, aspirantiv, magistriv ta studentiv (Ukraine, Kyiv, 2020), Kyiv: Muzyka $\mathrm{v}$ dialozi z suchasnistyu: mysteczki, pedagogichni, komunikacijni aspekty muzychnoyi kultury Ukrayiny XXI stolittya, pp. 204-206.

6. Tsiuriak I. O., Fedorchenko V. K., Borysenko N. S. (ed.) (2018) Rekomendaciyi dlya samostijnoyi roboty studentiv mysteczkykh specialnostej [Recommendations for independent work of students of art specialties]. Zhytomyr: ZhSU named after Ivan Franko. (in Ukrainian)

7. Faryna N. P. (2018) Koncertno-vykonavska diyalnist studentiv-vokalistiv: pedagogichnyj aspect [Concert and performance activities of student vocalists: pedagogical aspect]. Scientific View: Art Education and Development of Creative Personality, no. 4, pp. 124-130.

8. Faryna N. P., Tymoshenko T. G. (2020) Studiya estradnogo spivu v suchasnij systemi mysteczkoyi osvity [Studio of pop singing in the modern system of art education]. Scientific View: A new pedagogical idea, no. 1(77), pp. $143-147$.

9. Cherkasov V. F. (2017) Osnovy naukovykh doslidzhen u muzychnoosvitnij galuzi: pidruchnyk [Fundamentals of scientific research in the field of music education: textbook]. Kharkiv: KSPU named after V. Vynnychenko. (in Ukrainian) 